\title{
Africanising Philosophy for Children (P4C) in the South African Context
}

\author{
Matsephe M. Letseka \\ Department of Educational Foundations, \\ College of Education, University of South Africa \\ E-mail: letsemm@unisa.ac.za
}

\section{Doi:10.5901/mjss.2014.v5n9p348}

\begin{abstract}
The paper explores ways in which philosophy for children (P4C) can be Africanised in South Africa. Africanisation is taken to mean a thought world enveloped in African idioms and symbols, the recognition of a diversity of ways of knowledge and alternative epistemologies, and a variety of ways of learning and understanding the world of experience and of constructing the future. Africanisation calls for the teaching and learning that privileges the deliberate and critical engagement with Africa, African histories, African cultures, African countries, African peoples, African promises and African challenges, past and present. At a practical level in the classroom Africanising P4C implies the teaching of school subject through storytelling that is 'rooted in Africa'. The paper sketches the notion of P4C, and posits that it should not be about teaching the views of particular philosophers. Instead it should be about equipping children with critical thinking skills and engaging them in a structured search for meaning. The stories that are told in order to promote $P 4 C$ are on animals and nature and have a heuristic value in that they contribute towards the children's attainment of moral and philosophical literacy.
\end{abstract}

Keywords: philosophy for children (P4C); Africanisation; storytelling; reflexivity; South Africa

\section{Introduction}

In my research on African philosophy and philosophy for children (P4C) in South Africa, ${ }^{1}$ I make an impassioned plea for students of philosophy of education at my institution, which is an open distance learning (ODL) institution, to differentiate between, on the one hand, African philosophy as an all-encompassing discipline marked by ethno-philosophy, philosophic sagacity, nationalist-ideological philosophy and professional philosophy (Oruka (2002, 1990), and on the other hand, African traditions and cultures, or worldviews, as in the case of Ubuntu in Southern Africa. I advocate a deeper understanding of African philosophy through P4C (Letseka, 2013a), and make a case for the introduction of critical thinking skills in primary schools through P4C (Letseka \& Venter, 2013b). In this article I draw from all these contributions to ponder over ways in which P4C can be Africanised in school curriculum in South Africa. I propose a hermeneutic approach that is undergirded by phenomenological and reflexivity paradigms. The key issue here is to engage children in stories that whet their appetite for interpreting and appropriating their own lived experiences while at the same time reflecting on these lived experiences and juxtaposing them with those of others in different circumstances. Hermeneutics questions the putative neutrality of reading a text and places meaning at the centre of inquiry (Eger, 1993). Crucially though, hermeneutics fosters philosophical dialogues reminiscent of those found in Plato's dialogues such as The Republic, Meno, Euthyphro, Apology, and Protagoras (Letseka \& Zireva, 2013). Phenomenology aims to unpack the meanings of our everyday-life-world. It seeks fresh, complex and rich descriptions of a phenomenon as it is concretely lived. Reflexivity is about intersubjective and retrospective reflection. It can promote rich insight through examining personal responses and interpersonal dynamics" (Finlay, 2003). Thus reflexivity can be regarded as a form of "discourse directed towards the self" (Adams, 2003: 229). What that discourse does is to excavate "layers of tradition which once formed the unquestioned, naturalised aspects of the self". As a result "the self turns back upon itself and becomes aware of the processes which, until that point, made it what it was" (Adams, 2003: 224).

This paper is divided into four sections. First, I briefly explore the notion of Africanisation in the Southern African

\footnotetext{
${ }^{1}$ Letseka, M.M. (2013a) "Understanding of African philosophy through philosophy for children (P4C)", Mediterranean Journal of Social Sciences 4 (14), 745-753; Letseka, M.M. \& Venter, E. (2013b) "Learning critical thinking skills through philosophy for children (P4C)", in Eldrie Gouws \& Charl Wolhuter (eds). Educational Research in South Africa: Practices and Perspectives, SAERA 2013 Conference Proceeding, Oxford University Press: Cape Town; Letseka, M.M. \& Venter, E. (2012) "How student teachers understand African philosophy", Koers - Bulletin for Christian Scholarship 77(1\&2), 1-8.
} 
context. The notion of Africanisation has been widely chronicled (Makgoba \& Seepe, 2004; Higgs, 2003; 2007; Higgs \& van Wyk, 2004; Waghid, 2004; Nakusera, 2004). Centrally, these scholars are making a case for Africanising higher education. In this paper my interest is on how P4C can be Africanised, and what such Africanisation consists in. Second, I delineate the parameters of P4C. My contention is that Africanisation can at best be addressed by embedding the notion at school level. To the end, my view is that for P4C to be a viable tool for understanding African philosophy, it should be "rooted in Africa" (Lenka-Bula, 2011). That is, it should draw on African stories and experiences as its base. Third, I sketch examples of how P4C can be Africanised. In the final section I provide some concluding remarks.

\title{
2. Africanisation
}

Many scholars have responded to the call to Africanise higher education (Higgs \& Van Wyk, 2004; Nakusera, 2004; Higgs, 2003, 2007; Waghid, 2004; Wiredu, 2004; Venter, 2004; Parker, 2000; Adeyemi \& Adeyinka, 2003). Built into these responses is advocacy for an African philosophy of education as an approach for dealing with the discrepancies resulting from centuries of the influence of Western education in Africa. Makgoba \& Seepe (2004:19-20) argue that for a university to be truly African and to fulfil the challenge of Africanising its central intention should be to create

\begin{abstract}
"An institutional transformation in higher education that will provide for the production of knowledge that recognises the African condition as historical and defines its key task as one of coming to grips with it critically... The African University should be the custodian of African knowledge, both aesthetic and functional, so that it can dictate terms of appropriation to the world".
\end{abstract}

\section{Similarly, Lebakeng (2004:115) contends that}

\begin{abstract}
"The dire need for Africanisation, especially in relation to curriculum, is not simply a struggle for power, but is an exigency of justice that demands the restoration of equilibrium in the contending epistemological paradigms between the alien conqueror and the indigenous African conquered... It is imperative that South Africa develops theoretical models underpinned by indigenous African philosophy so as to interpret correctly and coherently the problems and prospects of a democratising society".
\end{abstract}

The winter 2011 Issue of the University of South Africa (UNISA)'s magazine UNISAWISE features a lead story titled "Rooted in Africa", which made an impassioned advocacy for the Africanisation of teaching, learning and research in South Africa. The question 'why Africanise?' then becomes pivotal. One of the primary contributors to the abovementioned lead story, Tinyiko Maluleke (2011:14) defines Africanisation as "a deliberate and conscious attempt to understand and situate one's epistemology, academic and research agenda and endeavours within an African milieu. It means the deliberate privileging of previously subjugated Africa knowledges, texts, contexts and experiences". Maluleke argues that "To seek to Africanise is both to choose that path of academic activism - the path of resistance - and to risk blazing trails where there are neither paths nor roads". He is quick to caution though that "Africanisation is not a romanticisation of Africa, African histories, African cultures, African countries or African peoples. Rather it is a privileging of the deliberate and critical engagement with Africa, African histories, African cultures, African countries, African peoples, African promises and African challenges, past and present". For Maluleke (2011:14), Africanisation is about "our ability to innovate and apply our research skills to address critical needs in Africa and the world". It is about "increasing the pool of Africans with the requisite skills for research production and innovation. It is therefore about ensuring a sustainable future for the higher education sector in this country and on the continent"

Writing in the same pages of UNISA's UNISAWISE Puleng Lenka-Bula (2011:10) argues that "at the heart of Africanisation lies the affirmation and restoration of the dignity of peoples in all their diversity, hues and shapes, including those who were 'dehumanised' or seen as secondary citizens or non-citizens in South Africa and Africa". She cites former UNISA professor of philosophy Mokgobe Ramose who contends that Africanisation is "essentially a thought world enveloped in African idioms and symbols, the recognition of a diversity of ways of knowledge and alternative epistemologies and a variety of ways of learning and understanding the world of experience and of constructing the future". Lenka-Bula (2011:12) refers to Cameroonian sociologist Francis Nyamjong, who argues that "Education in Africa has been, and mostly remains, a journey fuelled by an exogenously induced and internalised sense of inadequacy in Africans, and endowed with a mission of devaluation and annihilation of African creativity, urgency and value systems". Such cultural estrangement, Lenka-Bula argues, "has served to reinforce Africans' self-devaluation and self-hatred and a profound sense of inferiority that in turn compel them to lighten their darkness both physically and metaphysically in western gratification". For that reason Africanisation impels upon universities "to transform themselves into relevant 
institutions". For instance, some Asian and European universities have promoted local languages as medium of instruction, and yet many South African universities have shied away from tuition in a variety of languages spoken in South Africa even though local languages are purveyors of local cultures and traditions. Higgs \& van Wyk (2004:205) argue that Africanisation can be achieved through a higher education that embraces communal life and Ubuntu, socioethical themes which transcend the culture, language and ethnic diversity of Africans. It is their contention that higher education discourse within an Africanising context would enable Africans to function in relation to one another in the communal tradition. Such functioning would be characterised by a spirit of Ubuntu in which human needs, interests and dignity are of fundamental importance and concern (Higgs \& van Wyk, 2004:205). This will not only foster the spirit of Ubuntu, but will also develop cooperative skills, which will promote and sustain the sort of communal interdependence and concern with the welfare of others that is encouraged by Ubuntu (Higgs \& van Wyk, 2004:206).

At a practical level Africanisation of education implies invoking some of the useful elements of African traditional education and adapting them to contemporary educational imperatives. Nigerian educationists Adeyemi \& Adeyinka (2003) make a case for the inclusion of the following principles of African traditional education in fashioning curriculum for contemporary African learners - preparationism, functionalism, communalism, perennialism and wholisticism (Adeyemi \& Adeyinka, 2003:431). I should mention from the outset that Adeyemi \& Adeyinka (2003:425) emphasise a call for a "return to the indigenous education system albeit in a modified form". What then does each of the above-mentioned principles presuppose? Preparationism regards teaching and learning as a way of equipping learners with skills appropriate for their gender. This implies that learners should be prepared to adjust to the community and play a useful role in it. Functionalism is a participatory kind of education, where learners learn through imitation, initiation ceremonies, work, play or oral literature. This allows learners to be productive as they learn and to be gradually integrated in the community. In communalism, the society owns items in common; children belong to the community and could be disciplined by any member of it. Under perennialism, education is viewed as a vehicle for maintaining and preserving the cultural heritage and the status quo. Wholisticism seeks to equip young people with related skills for doing different jobs, which makes them productive in many ways. Adeyemi \& Adeyinka (2003:432-433) do touch on the weaknesses and strengths of African traditional education towards the end of their article. It is important that they acknowledgement this point, which is why one of their advocacy is the need to modify some of the principles of African traditional education to fit in with contemporary African conceptions of education. For instance, the principles of preparationism, perennialism and wholisticism can be modified to make them non-gender specific. They would still prepare young people to adjust to the community and play useful roles which are not necessarily gender specific. The call by Adeyemi \& Adeyinka (2003:439) to reconcile what is good in African traditional education with positive aspects of Western education is necessary given that modern Africa is not pre-colonial Africa. For instance, instead of embracing the idea and practice of indoctrination, which traditional education is known for, modern day learners could be introduced to the idea of reflexive thinking (Adeyemi \& Adeyinka, 2003:438).

The notion of reflexivity is associated with, among others, French sociologist Pierre Bourdieu. In the introduction above I briefly alluded to the fact that reflexivity is about intersubjective and retrospective reflection and that it aims to promote rich insight through examining personal responses and interpersonal dynamics" (Finlay, 2003). I also underscored that reflexivity can be regarded as a form of "discourse directed towards the self" (Adams, 2003: 229). Drawing on Bourdieu, Guillemin \& Gillam (2004:274) posit that the reflexive process comprises taking two steps back from the subject of the research. The first step back is the objective observation of the research subject; the next step back is the reflection of the observation itself. It follows therefore that reflexivity is not a single or universal entity but a process - an active, ongoing process that saturates every stage of the research. Guillemin \& Gillam (2004:274) argue that reflexivity is a process of critical reflection both on the kind of knowledge produced from research and how that knowledge is generated. They posit that a reflexive researcher is one who is able to step back and take a critical look at his or her own role in the research process. The goal of being reflexive in this sense has to do with improving the quality and validity of the research and recognizing the limitations of the knowledge that is produced, thus leading to more rigorous research.

Given the importance African societies in general place on communities, it is not unusual that communalism has such special significance for Africanisation through African philosophy (Wiredu, 2004:21). As Higgs \& van Wyk (2004:208) maintain, "the discourse in higher education in South Africa needs to take note of the contributions that African philosophy can make to the transformation of higher education theory and practice". In the same vein Venter (2004:157) argues that education for community life is important from an African point of view, whereby communalism and respect for the community, which involve sharing with and helping others, take precedence. Venter calls for the integration of a pluralistic view of philosophy of life and cultural backgrounds into the school setting in order to solve problems and for cultures to co-exist in a meaningful way. Letseka (2000:189) also makes a case for communalism in his 
observation that "there is no doubt ... that interpersonal and cooperative skills are sine qua non to traditional African life". These skills help to promote communally accepted and desirable moral norms and virtues (Letseka, 2000:189). It is his contention that the inculcation of cooperative skills in young people will play a crucial role in promoting and sustaining communal interdependence and concern with the welfare of others (Letseka, 2000:189).

Nowadays, most African scholars are of the view that in order for education to benefit communities, indigenous knowledge systems (IKS) must be integrated into the education system. Some even argue that this will help improve the academic performance of African children, especially in mathematics and science subjects. For instance, Odora-Hoppers (2001:75) contends that African children do not perform well in these subjects because their prior knowledge of indigenous scientific and mathematical cosmologies is not always taken into consideration before the new subject contents are introduced. Universities are especially guilty as they, along with the disciplines they offer, "acquire that air of 'ethnographic exotica' in relation to society" (Odora-Hoppers, 2001:81). As a result they insulate themselves from society and protect the status quo, encapsulated and cocooned inside of their walls (Odora-Hoppers, 2001:81). In order to resolve this situation, Higgs, Higgs and Venter (2003:43) maintain that "indigenised innovations and knowledge systems would also have to be taken into account in higher education curricula". There should be new ways of thinking about the history, economics and social status of local IKS in South Africa (Higgs et al., 2003:43). For Higgs et al. (2003:44), indigenous knowledge is used by communities for making decisions about food, human and animal health, education and other activities. As part of the community "the higher education sector needs to support local and regional networks of traditional practitioners and help disseminate useful and relevant indigenous knowledge so that communities can participate more actively in ongoing development processes" (Higgs et al., 2003:44).

It is no coincidence therefore that scholars and intellectuals are in the forefront of advocacy of African philosophy as a basis for conceptions of education in (South) Africa. In 2000, the then minister of education South Africa, Professor Kadar Asmal, initiated the formation of a working group on values in education. The group released a report on the promotion of values such as equity, tolerance, multilingualism, openness, accountability, and social honour in schools (DoE, 2000:6). These are the values which African philosophy and Ubuntu espouse. The report identifies the notion of Ubuntu as key to enabling individuals to attain tolerance - a state of human consciousness that requires truthfulness about the failures and successes of the human past (DoE, 2000:22). Ubuntu also features in another Department of Education publication on values, which observes that

\begin{abstract}
"out of the values of Ubuntu and human dignity flow the practices of compassion, kindness, altruism and respect which are at the very core of making schools places where the culture of teaching and the culture of learning thrive; of making them dynamic hubs of industry and achievement rather than places of conflict and pain..., Ubuntu embodies the concept of mutual understanding and the active appreciation of the value of human difference.... Ultimately, Ubuntu requires you to respect others if you are to respect yourself" (DoE, 2001:14).
\end{abstract}

From the discussion of various scholars above, it is evident that Africanisation holds a significant place and is expected to play an important role in education in South African. The basis for this is that the common thread among scholars and researchers is that Africanisation should occur in higher education. However, my position in this paper is that Africanisation should begin at schooling level. School children should be immersed in values such as Ubuntu and communalism from an early age to ensure that by the time they are ready to enrol in higher education they will have grasped the necessary values that pertain to the Africanisation drive. Since there is a perception that teaching philosophy to school children would be too much of a higher order pursuit for them to grasp (Kitchener, 1990; White, 1992), one way of introducing philosophy to school children is through philosophy for children or P4C, to which I briefly turn in the next section.

\title{
3. P4C
}

In the 1970s philosophers such as Matthew Lipman and Margaret Sharp developed P4C with a view to introducing children to philosophising and thinking critically at an early age. These philosophers based their work on Vygotsky's theory, which considers learning through instruction rather than age as a fundamental feature of human intelligence (Roberts, 2006:12). Vygotsky's theory is important in that it highlights the role played by adults (teachers, parents, educators), peers and others in fostering and enhancing cognitive development in children, through communication, language and social interaction (Roberts, 2006:12).

P4C aims to integrate "the methods and content of philosophy and pragmatic ideal of community inquiry in order to facilitate critical, creative, caring, and communal thinking skills, as well as the social skills and attitudes necessary for 
democratic citizenship" (Bleazby, 2011:453). The community of inquiry has its roots in the times of Socrates and is premised on the assumption that "deliberative and collaborative communities are exceptional in their ability to foster critical, creative and caring thinking, leading to sounder reasoning, understanding, and judgement" (Lipman, 1998:278). For P4C practitioners the classroom becomes a community in which emphasis is placed on "dialogue and reflection, with the class discussion building upon the philosophical issues present in the philosophical novels for children" (Hagaman, 1990:151). Lipman and Sharp believed children can learn philosophy at an early age. They demonstrated that as much as the "proper teaching of history generates historical thinking, and the proper teaching of mathematics generates mathematical thinking, so the proper teaching of philosophy must generate philosophical thinking" (Lipman \& Sharp, 1978:85). This argument is endorsed by Murris (2000:263), who argues that primary school children do not study mathematics or history as capably as professional mathematicians or historians, and yet there has never been a call for them not to study these subjects. Young children might not engage in complex philosophical arguments as adults or professional philosophers would, but they can be taught from an early age in order to be able to engage in such arguments later in live. As Murris (2000:263) points out, abstract concepts do not just develop but can be taught. Relying on Vygotsky's theory, Murris contents that training is more important than age in developing philosophical inquiry.

Philosophy should be an enjoyable subject for children if their interest in it is to be cultivated. For example, one way of making the teaching and learning of philosophy interesting for children is through the use of children's stories and poetry. Lipman \& Sharp (1978:86) assert that:

"Children for whom the formal presentations of philosophy are anathema may find hints of the same ideas entrancing when embedded in the vehicle of a children's story. Young people who find the writing of a philosophical essay unthinkable can be induced to express philosophical notions in verse with little apparent reluctance".

P4C has been criticised by some philosophers who are convinced that philosophical reflection is too complicated for children. These criticisms stem from Piaget's theory of stages of development, which claims that cognitive development is a natural progression and has clearly definable stages (Lyle, 2000:46). Piaget's cognitive development stages are lucidly summarised by Roberts (2006:8):

\begin{abstract}
"Piaget emphasised that children pass through a series of four cognitive developmental stages before they construct the ability to perceive, reason and understand in mature and rational ways. The sensorimotor stage (birth to 2 years) is characterised by behaviour that is goal-directed, with goals moving from concrete to abstract. The preoperational stage ( 2 to 7 years) is characterised by the acquisition of semiotic functioning and the engagement in symbolic and language games, and a difficulty in seeing another person's point of view and where thought and communication are egocentric. The concrete operational stage (7 to 11 years) is characterised by the performance of true mental operations and solving of concrete problems in a logical fashion, and a difficulty in thinking hypothetically and in systematically considering all aspects of a problem".
\end{abstract}

One of the most notable implications of Piaget's theory is that "children have to reach a particular cognitive developmental stage to be able to reason about abstract matters and think philosophically" (Roberts, 2006:10). Piaget's view that children under 7 years are at a pre-logical stage and cannot engage in formal operations was challenged by Lipman, who argued that philosophically, children are likely to ask more interesting questions than adults (Vansieleghem \& Kennedy, 2011:175).

Elsewhere (Letseka \& Venter, 2013:119) I have dealt with critics of P4C (Kitchener, 1990 and White, 1992 and 2011). I have argued that these criticisms are not that compelling. Instead they actually support what P4C is meant to do, which is to teach children critical thinking skills, which would in the end help children to develop independent and critical reading of their study materials by the time they enrol in higher education. White's (2011:9) suggestion that if improving school children are reasoning in the fields of politics, practical problems, relationships, and artistic reasoning is what education ought to be about, this in fact supports the view that P4C teaches critical thinking skills, which has the potential to engender philosophising among the children as they grow and mature. It is my contention that the criticisms should not detract from the potential P4C has for improving children's critical thinking skills and helping them become better philosophers in future. I have argued in another article (Letseka, 2013: 751-752) that because of its similarities with some of the principles of African philosophy such as communalism and Ubuntu, P4C also has potential to help students understand philosophy better. While I have argued a case for P4C's potential in clarifying how African philosophy works due to its similarity with African philosophy, it is still a Western concept, with most of its teaching and learning materials derived from Western countries where it originates. The main focus of this article is to find ways of Africanising P4C to make it more enjoyable and relevant to learners in South African schools. The next section is a discussion of this issue. 


\section{Africanising P4C}

In the previous section, I alluded to the similarity between P4C, through the community of inquiry, and some of the principles of African philosophy such as Ubuntu and communalism. My contention is that these similarities would make P4C an appropriate vehicle for understanding how African philosophy works. Furthermore, if the struggle to Africanise Higher Education is to succeed, Africanisation should begin at school level. As Ndofirepi, Shumba, \& Musengi (2013:37) assert, "if we agree that African philosophy is a response to the cultural identity crisis and that its discourse is to reconnect philosophy with indigenous intellectual practices..., then an African perspective of Philosophy for Children should do the same". If this is what P4C should do, then it should be presented to the children from an African point of view through story telling. In schools, P4C should not be about teaching the views of particular philosophers like Socrates, Plato, Dewey, or Wiredu. Rather it should be about equipping children with the tools for thinking, engaging them in the search for meaning (Ndofirepi, 2011). In this section, I briefly explore ways of Africanising P4C through story telling.

\subsection{Using stories from Southern Africa}

Lipman did not intend to teach children philosophy in the way it is done at colleges and universities. His take was that this could be done through children's stories, which children would relate to. The stories would be used to help children discover "how their own thought processes work, and how more effective thought processes could be distinguished from less effective ones" (Lipman 1976:17). That is, he envisioned P4C resulting in the development of critical thinking skills among children. In this regard critical thinking is taken to mean being able to make a distinction between better and weaker ways of reasoning in addition to which better ways are defined under the category of analytical thinking. According to this logic a critical thinker is someone who has at his or her disposal analytical thinking skills to acquire knowledge about underlying presuppositions: it is someone who in his or her thoughts and actions is guided by knowledge and logical principles as a source to make analyses and speculations (Vansieleghem, 2013). Storytelling for critical thinking is predicated on existence of communities of inquiry. Haynes (2013) observes that through the community of inquiry one learns the judgement necessary to adjust critically to the values of others or persuade others to adjust, and that requires the tools of reasonableness. She opines that "the community of inquiry to engage the child emotionally as well as intellectually, to link and connect ideas, to challenge them to give and seek reasons for different points of view, to demand conceptual clarity and to create a disposition to understand rather than dismiss opposing views, all of which should lead to an awareness of each child's place in a fluid and growing community where difference is celebrated" (Haynes, 2013:5). I should mention that stories also offer valuable moral lessons. In West African Folk Tales VernonJackson (2003) argues that stories and folktales contain narratives that teach valuable lessons, among others, in the importance of obeying one's parents and of acts of kindness. Moreover stories and folk tales expose children to crosscultural experiences that they can debate in class with the guidance of the teacher in order to derive deeper understanding. As Sackey (1991: 405) reminds us, "African oral tradition is an integral part of African life, and so it is the African cultural context that gives African oral tradition meaning and purpose".

In South Africa Christie \& Mhlophe (1996) argue that "traditionally in African culture, storytelling was something that happened at the end of the day. People would come home when they had done their chores and children would wait for the sun to go down. Then, at that special time when everything is beautiful, during the twilight as the first star appears in the northern sky, the children would look at their grandmothers expectantly for a story". This is because "grandparents were the guardians of language and the keepers of culture". During storytelling participants sit around together, at ease with one another and, as the appeal of the story cuts across age and sex boundaries, there is no passivity, and all come into a truly integrated community (Sackey (1991). Invariably the focus of the stories is on animals and nature, and lessons to be learned. Christie \& Mhlophe (1996) observe that within traditional African stories the animals symbolised different qualities. Some animals, such as the wolf are known to be greedy, others, such as the jackal and the hare are known to be tricksters; while the tortoise and the owl are associated with ancient wisdom. In some stories the jackal saves human beings, while the eagle represents a sharp vision and the ability to reach the highest levels of creativity. Thus in Africa stories have heuristic value in that they help children achieve moral literacy (Collins, 2010).

South Africa's Award winning story teller Gcina Mhlophe has written numerous children's stories such as African Tales; Stories of Africa; Our Story Magic; Mazanendaba and the Magical Story Shell; What's Love in your Language? Ithemba means Hope; Fudukazi's Magic, to mention a few. To take Fudukazi's Magic (Mhlophe, 2009) as an illustration, the book, which is suitable for primary school children in Grades 2, 3, and 4 takes the children through a journey of imagination into the beginning of time when all the animals were dull brown and unhappy with the way they looked. 
Fudukazi is a wise old Tortoise who uses her imagination and magic to decorate the world colourfully. Among the animals that benefit from Fudukazi's magic are the Leopard, the Giraffe, and the Zebra. In the beginning these animals, like all other animals were dull brown and unhappy with the way they looked. Fudukazi meets the dull, brown, unhappy and depressed Leopard and offers to help. She asks Leopard to close her eyes while she weaves her magic around her. The story then reads:
"When Leopard opened her eyes she saw that she had a beautiful ivory coloured coat with brown spots all over. She jumped up and down, laughing.
"Oh, thank you Fudukazi! You lovable wise tortoise".
She ran, not knowing where she was going, too happy to think. She came to a place where many women were working in the fields near a village. They were so amazed by her beauty.
"What aminal is that? Let's cach it, I want it to be my pet". Said one woman. But Leopard ran faster and disappeared in the bush.

When the story of the magic of Fudukazi started to spread, Giraffe also wanted to wear one of the beautifu coats and she immediately paid Fudukazi a visit. The listener is told Giraffe was so tall he almost stepped on Fudukazi's shell in hurry. He asked:

"Please Fudukazi, I saw Leopard's new coat. Won't you give me one too?"

Once again Fudukazi told Giraffe to stand still, close his eyes and make a wish. Giraffe did as he was told, wishing with all his heart to be good looking. Again Fudukazi moved around Giraffe singing her song, and eventually told Giraffe to open his eyes. Giraffe was so pleased with his new coat.

"Thank you, Fudukazi, respectable old Tortoise! I'm so happy". He walked away feeling like a new man.

I mentioned above that some of the narratives contained in stories and folktales touch on acts of kindness, which revolve around the area of moral literacy. At this stage the teacher might want to pause and initiate discussions to a series of questions.

- Do you like what Fudukazi is doin? Why?

- If Fudukazi had not changed Leopard and Giraffe's coats can you imagin how they would still be feeling?

- Have you seen a live Leopard and a Giraffe? How do they look like

- Do you think Fudukazi did a good job? Why is that the case?

The aim of the discussion here would be to use probing questions to get the children to discuss among themselves and to express their views on, and appreciate acts of kindness such as Fudukazi's. This story would also appeal to learners in South Africa as the animals such as tortoise are given local names, which the learners can identify with.

\section{Conclusion}

What I have attempted to do in this paper is to delineate the notion of Africanisation in the South African context. I argued that Africanisation presumes that the teaching, through storytelling should be 'rooted in Africa'. That is, it should draw on, and be framed by the African stories and experiences. It should privilege the deliberate and critical engagement with Africa, African histories, African cultures, African countries, African peoples, African promises and African challenges, past and present. I briefly sketched the notion of P4C, and argued that it should not be about teaching the views of particular philosophers. Rather its aim should be about equipping children with critical thinking skills and engaging them in the search for meaning. Finally, I opined that storytelling in order to promote P4C should focus on animals and nature given that in Africa stories have heuristic value that contributes towards the children's attainment of moral and philosophical literacy.

\section{References}

Adams, M. (2003) "The reflexive self and culture: a critique", British Journal of Sociology, 54 (2), 221- 238.

Adeyemi, M. B. \& Adeyinka, A.A. 2003. The principles and content of African traditional education. Educational Philosophy and Theory, 35 (4):425-440.

Bleazby, J. 2011. Overcoming relativism and absolutism: Dewey's ideals of truth and meaning in philosophy for children. Educational Philosophy and Theory. 43 (5):453-466. 
Collins, L. (2010) "Autonomy and authorship: storytelling and children's picture books", Hypatia, 25 (1), 174-195.

Christie, P., \& Mhlophe, G. (1996) Sawubona Africa, Embracing Four Worlds in South African, Zebra Press: Johannesburg,

Department of Education (DoE) (2000) The Report on Values, Education and Democracy. South Africa: Conxtions Development Communications.

Department of Education (DoE) (2001) Manifesto on Values, Education and Democracy. Pretoria: Department of Education.

Eger, M. (1993a) Hermeneutics as an approach to science: Part I, Science \& Education 2:1-29.

Finlay, L. (2003) "Introducing reflexivity", in Linda Finlay \& Brendan Gough (eds) Reflexivity: A Practical guide for Researchers in Health and Social Science, Blackwell Science: Oxford.

Guillemin, M., \& Gillam, L. (2004) "Ethics, reflexivity, and ethically important moments in research", Qualitative Inquiry, 10 (2), $261-280$.

Hagaman, S. (1990) "The community of inquiry: an approach to collaborative learning", Studies in Art Education, 31 (3), 149-157.

Haynes, F. (2013) "Editorial", Educational Philosophy and Theory, published by the Taylor \& Francis on-line 13 Mar 2013. http://dx.doi.org/10.1080/00131857.2013.771442

Higgs, P \& van Wyk, B. (2004) "Towards an African philosophy of Education", South African Journal of Higher Education, 18 (3), $196-210$.

Higgs, P., Higgs, L. G. \& Venter, E. (2003) "Indigenous African Knowledge systems and innovation in higher education in South Africa", South African Journal of Higher Education, 17 (2), 40-45.

Kitchener, R. (1990) "Do children think philosophically?", Metaphilosophy, 21(4), 416-431.

Lebakeng, T. (2004) "Towards a relevant higher education epistemology", in Towards an African Identity of Higher Education, edited by Sipho Seepe Pretoria: Vista University and Skotaville Media, pp.109-119.

Lenka-Bula, P. (2011) "Africanisation at UNISA", UNIWISE, UNISA Press: Pretoria, pp. 10-12.

Letseka, M. M. (2013) "Understanding of African philosophy through philosophy for children (P4C)", Mediterranean Journal of Social Sciences 4 (14), 745-753.

Letseka, M. M. \& Venter, E. (2013) "Learning critical thinking skills through philosophy for children (P4C)", in Eldrie Gouws and Charl Wolhuter (eds). Educational Research in South Africa: Practices and Perspectives, SAERA 2013 Conference Proceeding, Oxford University Press: Cape Town.

Letseka M. M. (2012) "An analysis of undergraduate philosophy of education students' perceptions of African philosophy", unpublished DEd thesis, College of Education, University of South Africa (UNISA).

Letseka, M. M. \& Venter, E. (2012) "How student teachers understand African philosophy", Koers - Bulletin for Christian Scholarship 77(1\&2), 1-8.

Letseka, M. \& Zireva, D. (2013) "Thinking: lessons from John Dewey's How We Think", Academic Journal of Interdisciplinary Studies, 2 (2), 51-60.

Letseka, M. 2000. African philosophy and educational discourse. In African Voices in Education, edited by P. Higgs, N.C.G. Vakalisa, T.V. Mda and N.T. Assie-Lumumba Landsdowne: Juta:179-193.

Lipman, M. (1998) "Teaching children to think reasonably: some findings of philosophy for children program", The Clearing House, 71 (5), $277-$ 280.

Lipman, M. \& Sharp, A. M. (1978) "Some educational presuppositions of philosophy for children", Oxford Review of Education, 4 (1), 85-90.

Lipman, M. (1976) "Philosophy for children", Metaphilosophy, 7 (1), 17-33.

Makgoba, M \& Seepe, S. (2004) "Knowledge and identity: an African vision of higher education transformation", in Towards an African Identity of Higher Education, edited by Sipho Seepe Pretoria: Vista University and Skotaville Media pp.13-57.

Maluleke, T. S. (2011) "Can research be Africanised", UNIWISE, UNISA Press: Pretoria, pp.13-14.

Mhlophe, G. (2009) Fudukazi's Magic, Cambridge University Press: Cambridge, UK.

Murris, K. (2000) "Can children learn philosophy?", Journal of Philosophy of Education, 34(2), 261-279.

Nakusera, E. (2004) "Rethinking higher education transformation in terms of African(a) philosophy of education", South African Journal of Higher Education, 18 (3), 127-137.

Ndofirepi, A.P., Shumba, A. and Musengi, M. (2013) "Philosophy for children in Africa: Is the hermeneutic- Narrative approach the answer?", Anthropologist, 15 (1), 33-42.

Ndofirepi, A. P. (2011) "Philosophy for children: the quest for an African perspective", South African Journal of Education, 31:246-256.

Odora-Hoppers, C. (2001) "Indigenous Knowledge systems and academic institutions in South Africa", Perspectives in Education, 19 (1), $73-85$.

Oruka, H. O. (2002) "Four trends in current African philosophy", in Philosophy from Africa, $2^{\text {nd }}$ edition, edited by P.H. Coetzee \& A. P.J. Roux, Oxford University Press: Cape Town, 120-124.

Oruka, H. O. (1990) Sage Philosophy: Indigenous thinkers and modern debate on African philosophy, E. J. Bill: Leiden.

Parker, B. (2003) "Back on the chain gang: some difficulties in developing a (South) African philosophy of education", Journal of Education, 30:23-40.

Roberts, A. F. (2006) "The Effects of Development Programme Based on Philosophy for Children", unpublished Master's thesis, Cape Town: University of the Western Cape.

Robinson, W. (1995) "Why "philosophy for children?", Early Child Development and Care, 107:5-15.

Sackey, E. (1991) "Oral Tradition and the African Novel", Modern Fiction Studies, 37 (3), 389-407.

Vansieleghem, N. (2013) "What is Philosophy for Children? From an educational experiment to experimental education", Educational Philosophy and Theory, published by the Taylor \& Francis on-line 13 Mar 2013.

Vansieleghem, N., \& Kennedy, D. (2011) What is philosophy for children, what is philosophy with children - After Matthew Lipman?", Journal of Philosophy of Education, 45 (2), 171-182 http://dx.doi.org/10.1080/00131857.2013.771442

Venter, E. (2004) "The notion of Ubuntu and communalism in African educational discourse", Studies in Philosophy and Education, 23: 149-160.

Vernon-Jackson, H. (2003)West African Folk Tales, Dover Publications: New York.

White, J. (2011 'doubts about philosophy for children", Philossophy of Education Society of Great Britain Britain Newsletter, December, pp.8-9.

White, J. (1992) "The roors of philosophy", in The Impulse to Philosophise, edited by A. P. Griffiths, Cambridge University Press: Cambridge, pp.72-88.

Wiredu, K. (2004) "Prolegomena to an African philosopher of education", South African Journal of Higher Education, 18 (3), 17-26. 